\title{
Measurements and Conventions
}

Measurements of lengths and widths are given in traditional units of shaku and ken, followed by metric conversions in parentheses. The currency units in common circulation between 1871 and 1953 were yen, sen, and rin (1 yen equaled 100 sen or 1,000 rin).

Names of Japanese places and sites are transliterated in ways to avoid cross-language redundancy as much as possible: for example, Nanzenji rather than Nanzenji Temple; Ōten Gate rather than Ōtenmon Gate; Keiryū Bridge rather than Keiryūbashi Bridge. Japanese personal names appear in the customary manner, with the surname before the given name. For clarity's sake, the book calls Emperors Meiji, Taishō, and Shōwa by these posthumous names when discussing them during their reigns; in contrast, it calls them by their given names, Mutsuhito, Yoshihito, and Hirohito, when discussing them in their roles as crown princes. An exception is made for the current emperor (at the time of writing), who is Akihito during his reign, not Heisei.

All translations are my own unless otherwise indicated. 
